\title{
AISTHETON IN THE TIME OF SOCIO-POLITICAL CRISIS
}

\author{
A B S S T R A C
}

The main attempt in this paper is to propose the understanding of the relations between aesthetics and the politics in the thought of Jacques Rancière as a theoretical instrument for implementation in a concrete situation of the protest. From here on, the protest is taken not only as a live social event, but, even more, as a bodily experience with the consequences and results that are occurring out of it. Starting from Rancière's position of the distribution of the sensible and the ways in which the muted subject has to attain his/her right of a speech, the paper deals with several topics across which one can conclude that only the corporeal presence during the protest itself enables the subject to sense the act sensibly. This is a rather different approach to the sensible understanding of the world and the experiences known as the relation between the art and the aesthetics, addressing the aistheton as a simultaneous carrier of denotation of the political. The case study used for this implementation is the so called Colourful Revolution and the "colouring" of the Macedonia Gate in Skopje, Republic of Macedonia.

\section{NebojšaVilić}


According to Jacques Rancière, the essence of politics is in the dissensus. Therefore:

1. The political (as a dissensus) exists only in the course of the occurrence of demonstration (or manifestation, that is, in the act of announcement, display, appearance as a confirmation of existence) in the realm of publicity, particularly in an open public space - the street.

2. The gap, that open and never completely filled space, occurs as a state of the sensible and this (or such) state appears (or is only possible) only when inequality and different interests of the social groups take place, that is, when some of those groups are deprived of the right to speak.

3. The mode to attain the right to that speech is the bodily presence at $a$ protest.

In view of the said, corporeality becomes a prerequisite and a necessary praxis of each and everyone's creation in the time of socio-political crisis.

The essence of politics is dissensus. Dissensus is not a confrontation between interests or opinions. It is the demonstration (manifestation) of a gap in the sensible itself. Political demonstration makes visible that which had no reason to be seen; it places one world in another. ${ }^{1}$ (emphasis added)

The political dissensus is the opposite of and the reaction and resistance to the political consensus, whereas the protest is a form of opposing.

In the more recent theory, the one of the past fifteen years, the fate concept is the one generally prevailing, that is, the conditions in the current actuality are accepted as a predestiny that cannot be altered; accordingly, they are a must impossible to change because the previous narratives of attempts for their changes have sufficiently shown them unsuccessful. At first glance, such neoliberal, relativising strategies, that Rancière most illustratively depicts with the concept and strategy of reaching a consensus, appear as adequately convincing and the only possible ones. The anti-historicity, which underlies those concepts, seems more inclined to introduce disorder rather than to put things in their sequenced order; it is achieved by excluding or more precisely by giving an all relative character to the epistemological methods which constitute the theory of knowledge and cognition.

Therefore, the current practices appear less interested in knowledge and increasingly inclined to mediation (either in the sense of agentry [agency] that produces, creates, a particular result, or in the sense of using/taking advantage 


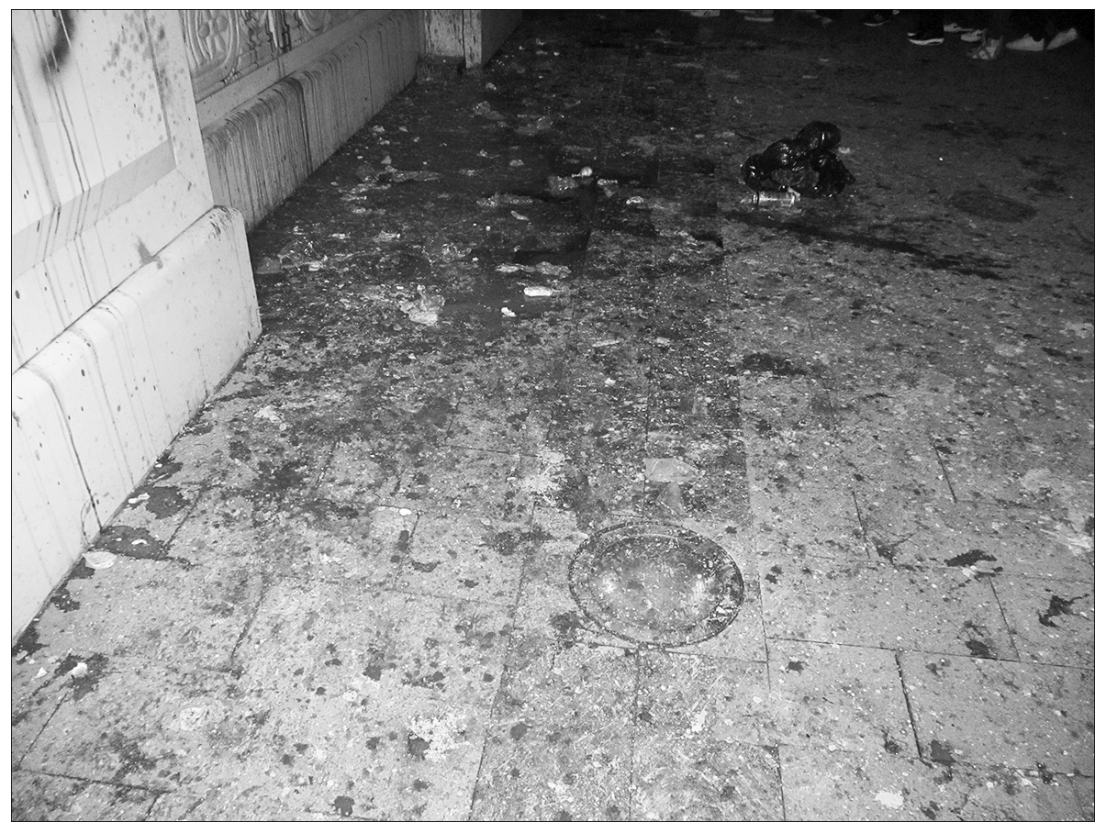

Figure 1. From the first "colouring" of the Macedonia Gate, April 15 2016. (Source: Author) 
of the utmost importance that the media has, mainly the technological one, although aware of their manipulability). Thus, the opinion prevails over the justified belief or over the valuation in particular. Although arguing that the systems of government must be subject to audit, even to reforms - in order to modernise them (to be in the spirit of time), they either omit the possibility or intentionally do not use it to offer or suggest, even impose another value system.

Sufficient arguments for additional criticism can be found in the thesis of Konrad Paul Liessmann which holds that "reforms are made for something to never be reformed, that is, for the condition to remain a status quo, that is, lest the situation should lead to a conflict," "2 thus manifesting the strategy of consensus that Rancière opposes to the strategy of dissensus.

Using the said as a point of departure, and in order to make distinction between these notions, I would like to highlight a single manifestation of Шарената револуција (The Colourful Revolution): "the painting" and "the colouring" of as well as the graffiting on Порта Македонија (The Macedonia Gate) (Fig. 1). The name The Colourful Revolution came into being later, only after a series of protests in Skopje, Republic of Macedonia, which began on 12 April, 2016, i.e., after the president of the state - Gjorge Ivanov, had announced his official decision for pardoning a good number of politicians of the ruling political party VMRO DPMNE (The Internal Macedonian Revolutionary OrganisationDemocratic Party for Macedonian National Unity) whose names appeared in the wiretapped talks released in the public by the opposition SDSM (Social Democratic Union of Macedonia). These protests occurred in between the two, brokered, Pržino Agreements (July 2015 and June 2016), both of which, as a political consensus, were a tool to resolve the socio-political crisis in the Republic of Macedonia in that period.

\section{I}

In a commentary, Bojan Ivanov substantially determines the character of the protest (as a form and a mode of demonstration):

The main purpose of the series of protests Every Day at Six [a series of protests during 2015 and 2016 which preceded the Colourful Revolution] ... is to make the communities of isolated individuals merge and grow into one and into a common platform from which - at least briefly - a peek in the historical time will be possible and the social contents of freedom for everyone and freedom for all will be within their reach. ${ }^{3}$ 
Collectivisation (of individuals to become a collective) is the state in which the individuation of the artistic act (defined by Ivanov as "an event, a sensible sign of reality"), in the actual present, can neither function nor generate content which would motivate the collective to a concurrent activity. Here I do not refer only to the involvement (participation) in the event as in a collective creative act, but also to the experiences of catharsis from/in/with the event. It is this point at which the dilemma over spectacularisation arises, that is, the branching of the very occurrence into an event (spectacle) and followers (spectators) of the event (but not participants). However, in a way, it is Althusser's post-Marxist presumption of the necessity of someone who will represent the interests of the members of the community as a collective, that is, someone else who will speak out in the name of the silenced ones (muted speech). At this point we need Rancière's criticism of this post-Marxist stance: it is the equality of the individuals that should be conquered personally by each individual. Hence, is it possible to speak out in plurality?; is it possible to speak out in the name of the deprived majority?, and without taking a "look at the historical time", as Ivanov has suggested?

Referring here to the imageness (and not of colourfulness - the covering with paints) that the "Colourful" Revolution gained, I again have to refer to Rancière and the conclusion he provides after Barthes's analysis and structural division of the photograph into studium and punctum:

But the semiologist who reads the encoded message of images and the theoretician of the punctum of the wordless image base themselves on the same principle: a principle of reversible equivalence between the silence of images and what they say. The former demonstrated that the image was in fact a vehicle for a silent discourse which he endeavored to translate into sentences. The latter tells us that the image speaks to us precisely when it is silent, when it no longer transmits any message to us. Both conceive the image as a speech that holds its tongue. The former made his silence speak; the latter makes this silence the abolition of all chatter. But both play on the same interconvertibility between the two potentialities of the image: the image as raw, material presence and the image as the discourse encoding a history. ${ }^{4}$ (emphasis added)

The event-protest is not only painted(ness) but imageness by itself because as a single, an individuated collective experience it creates the referential "image" as a historically coded meaning for the history, more precisely, something that within this historical discursive apparatus connects this event with the ones already occurred and denotes it as the one which announces the ones that are to follow. 
Hence, my criticism has emerged regarding the determination of the "Colourful" Revolution as an assembly of, or gathering of either specific and particular individuals, or specific and particular groups as divergent (and not as diverse). So has the call for returning to the historical legacy of resoluteness and its iconography. Furthermore, to continue with Rancière's comparative analysis:

Photography did not become an art because it employed a device opposing the imprint of the bodies to their copy. It became one by exploiting a double poetics of the image, by making its images, simultaneously or separately, two things: the legible testimony of a history written on faces or objects and pure blocs of visibility, impervious to any narrativisation, any intersection of meaning. This double poetics of the image as cipher of a history written in visible forms and as obtuse reality, impeding meaning and history, was not invented by the device of the camera obscura. It was born before it, when novel writing redistributed the relations between the visible and the sayable that were specific to the representative regime in the arts and which were exemplified by dramatic speech. ${ }^{5}$ (emphasis added)

Isn't discursive decoding of history/the historic that is embodied ("as raw material presence") with this double poiesis of the imageness created by all participants in the event-protest?

In this sense: the "painting" would be or is an act of individuation on behalf of the artist as the creator of values and meanings; the "colouring" would be or is an act of collectivisation by the participants in the event, that is, those who create the event. Therefore, I agree with Ivanov that Every Day at Six is "the opportunity for the isolated individuals to merge and grow into a collective", and the common platform would be the only one bound to be i.e. the one that will have to establish firm positions and even more an "ideology as a list of aspirations...", "instead of subjective positions and micro-politics", as Ivanov would put it, which would enable the realisation of the projective objective of all these occurrences.

The incertitude over the realisation of this platform remains, but it is the only one that can avoid the danger of transforming the event from art into culture, because it is the culturalisation (becoming the subject of culturalism) that blunts the difference, or rather, the dissensus, for its strategy is to equalise, and instead of a cultural revolution (turning point), to get another counter-something, this time another cultural counter-revolution embodied in the society of imposed, ungrounded expectations, fictitious needs and pressurised desires. ${ }^{6}$ 
I I I

The use of Rancière's concept of the aesthetics in the political or of the aesthetic of/in the political (and not the aesthetics of/in politics) refers to the sensible and its distribution, and not to the Baumgarten concept of aesthetics or to the "philosophy of beauty" in the artistic terms. Thus, it is not about aesthetics in politics, that is, whether there is or not, or it is forcefully inserted, or more precisely - it is not about the "aestheticisation of the political", which is Debor's stance that I do not agree with. Finally, it is not about "embellishment" or "beautification" of the political, but about the sensible reaction experienced with the participation in the event itself, in this case - the protests, i.e., in the Colorful Revolution. It is in this sense that Rancière understands and uses "aesthetics", wanting to emphasise that the sensible happens even in the political.

In this sense is my differentiation between the words "painting" and "colouring" that is used: the first one denoting an individual act (in terms of artistic), and the latter - a collective act (in the sense of cathartic-activistic).

\section{IV}

Allow me to clarify my stance. A protest occurs as a reaction to several situations (or conditions). The most important one is when the decisions reached in the community by consensus (for instance the Pržino Agreement) affects a part of the community in the process that Rancière defines as policing, i.e. the mechanisms and the tools used (via the Parliament, or with an Agreement) for the decisions consensually reached by the governing structures in the name of the community to be organised, implemented, and obeyed (which should not be confused with the police and policemen as institutions for conducting control of the implementation of and obeying to the decisions). This is the point when the gap occurs, a division in which one of the parties is excluded (in the stated case it would be the one affected by the mode in which the Agreement is enacted), that is, it is the moment when the dissensus (disagreement) occurs and is expressed and demonstrated, and it is so because one group within the community is deprived of the right to its voice, more precisely, to express its opinion and this opinion to be taken into consideration, and finally accepted.

According to Rancière, it is how the political occurs: the political is the space of litigation (the process of taking legal action) in which the excluded can protest against the wrong, i.e. the injustice exercised over them.

(On the one hand, women were deprived of the rights guaranteed by the Declaration of Rights, those that belonged to all 'free and equal' men and demanded to have these rights denied to them. On the other, through 
their very protest, these women demonstrated a political capacity. They showed that since they could enact those rights, they actually possessed them). ${ }^{7}$

This means two things: the presence of the body, the bodyness, i.e., the corporeal presence in order to express things. The first one would be the politicised body, i.e., when the subject enters the public space with his/her own bodily presence and participates, and the second would be the dismuted speech - when the mute speech, ${ }^{8}$ the one of the silenced or forbidden to speak out is expressed, and above all - heard in that same space.

Thus, upon Rancière's stance again: "The aistheton, then, is two things in one. It is both pure materiality and a sign. The pure passion of the sensory event is at once the sign of a reality which is thereby made known," (emphasis added) a conclusion is reached that it is in the public event (the protest) that the mobbed person (who may not say his/her voice) with his/her presence (pure materiality) makes that microbiopolitical mobbing known, i.e., the muted voice becomes a loud voice, the unheard becomes heard - the invisible becomes visible: he/she exits their private and individual space and steps onto the public one. In line with the said, I can conclude that there is no space for the artistic in the protest as political; that the protest as a collective body can value the individual only as joint, and not as a separate or autonomous one.

Therefore, the occurrences of the "colouring" in the Colourful Revolution cannot be documented, but corporeally experienced as long as the protest lasts. This is probably the reason why watching the event on the TV news or in the photos and videos posted on Facebook, without any real participation, does not give the sense of the aesthetic in the political, i.e., the distribution of the sensible that happens in the course of the event named a protest. This time, whoever wants to sensibly experience the essence of the events and the actions in the time he/she lives in, will have to go to the protests instead of going to a museum, because the corporeality as political occurs only there and only then and at no other place or at any other time.

V

The only meaning of subjectivisation is exactly the subjectification in Rancière's sense of the word:

Subjectivisation [ $L a$ Subjectivation]: Alternately translated as 'subjectification' or 'subjectivation', la subjectivation is the process by which a political subject extracts itself from the dominant categories 
of identification and classification. By treating a wrong and attempting to implement equality, political subjectivisation creates a common locus of dispute over those who have no part in the established order. However, the very act of identifying these political subjects necessarily has recourse to misnomers, i.e. names that inadequately refer to the anonymous multitude that has no title in the police order. The logic of subjectivisation is therefore based on the impossible identification of political subjects, that is to say subjects who remain unidentifiable in the given field of experience and necessitate 'inaudible' modes of enunciation. ${ }^{10}$ (emphasis added)

It is because materialisation cannot be narrowed down only to reification of the thought, but to its release in the public space, the space of the public, where the contemplator, the creator, turns the act creation down into a social event as praxis. According to the modern ideas, each praxis as an opportunity for a new value to be designed, is an emancipatory act which is a prerequisite for equal rights and equality: "One need only learn how to be equal men in an unequal society. This is what being emancipated means." 11 As the other possibility is a complete opposite, that: "One must choose between making an unequal society out of equal men and making an equal society out of unequal men," 12 lest the prearranged situation of stultification should occur as an instrument of disidentification of the political subjects ("subjects who remain unidentifiable in the given field of experience and necessitate 'inaudible' modes of enunciation"13).

This sketch of the act of creation depicts the complexity of both the act of creation and its consequences. It also makes discernable the discursive practice and the discursiveness of the practice of creation. More precisely, it highlights the turning of the path of the author's sole act of creation into a social praxis which not only surpasses the authorship but deeply enters the profound sociality as - culturality.

If the Macedonian complex and radicalised sociality over the past period of more than three years is taken into account ${ }^{14}$, according to Bojan Ivanov, narrowed down to two essential components: Resistance and Protest versus the Regime, which are manifestation of the "obligation of the togetherness" as a contrariety, ${ }^{15}$ then it necessarily results that the transition from an individual authorship to the collective, social, and cultural is a prerequisite and a point of departure for a critical social practice which has to leave the particular field of arts (the thematic field of the critics' practice), to alter the currently absolute right to the use of aisthetis in the domain of arts, and to make it social just 
in the way Rancière does it. Namely, the holder, the object, the subject of inscription of the sensible, the so called aistheton, is translated from the art work onto the social (civic) subject. It implies that, performing the role of the emancipatory functions and policies of thinking and writing about arts, it itself becomes an object (aistheton) of social praxis both as a sign and materiality, and hence, as such, it becomes a kind of responsibility towards historicity: "It is not possible to think of today as of a content and to picture it as an activity outside the reality of the class, ideological boundaries and restraints over the individual - not until reality gains immediate relevance, i.e., historical one for the collective," adds Ivanov.

In line with this, such transformation of the creation (from author's action to a societal and cultural praxis) is also an act of both accountability and necessity for presence in the public space for:

The recursive logic of social movements has already reached the point from which the cycle of the encircling of the historic syllogism begins: the imaginary community of militant like-minded people (we-subject), is undergoing severe pressure for completion of the transformation into a collective of loyal co-fighters (we-object) which takes the role of effective, inertial driving force in the material inertia of the reificated world. ${ }^{16}$

In order to understand it and accept it, a new regime (possibly a fourth one) shall have to be applied - the one that Rancière presupposes, and that is the regime of experience, which holds that:

Even though art histories use to start from prehistoric rock paintings, Art only exists within a specific regime of identification that allows objects or performances made by very diverse techniques for very diverse destinations to be perceived as belonging to a unique mode of experience. It is not a mere question of the 'reception' of the art works. It is about the very fabric of experience within which they are produced. This fabric is constituted by concrete institutions - places for performance or exhibition, modes of circulation and reproduction - but also by modes of perception and affection, concepts, narratives and judgement which identify them and make sense of them. It is whole regime of experience that makes it possible that words, narratives, forms, colours, movements, and rhythms be perceived and thought as being art. ${ }^{17}$ 

(London and New York: Continuum, 2010), 38. (Скопје: Темплум, 2012); Konrad Paul Liessmann, Theorie der Unbildung. Die Irrtümer der Wissensgesellchaft (Wien: Paul Zsolnay Verlag, 2006).

Бојан Иванов, „Коментар“. [Ivanov, Bojan (2016a) 'Comment'.] [https://www.facebook. com/notes/nebojša-vilić/status-100-6832-што-ми-се-случи-во-четвртокот-на-5мaj-2016/10153801452193220/]

Jacques Rancière, The Future of the Image (2003), trans. Gregory Elliott (London and New York: Verso, 2007), 11.

Ibid., 11-12.

Tony Schirato and Jen Webb, "Selling the Visual," in Reading the Visual (Crows Nest: Allen \&Linwin, 2004), 151-168. Jacques Rancière, Dissensus. On Politics and Aesthetics. 57.

Jacques Rancière, Mute Speech. Literature, Critical Theory, and Politics. (1998), trans. James Swenson with an Introduction by Gabriel Rockhill ( New York: Columbia University Press, 2011). Jacques Rancière, The Aesthetic Unconscious. (2001), trans. Debra Keates and James Swenson (Cambridge, UK and Malden, MA: Polity Press, 2009), 92. Jacques Rancière, Mute Speech. Literature, Critical Theory, and Politics. 92. Jacques Rancière, The Ignorant Schoolmaster (1987), trans. Kristin Ross (Stanford, California: Stanford University Press, 1991), 133.

Ibid.

Ibid.

On 17 November, 2014, The International Students Day, the first students march was organised, thus beginning the series of marches and protests as an introduction of the whirl of protests over the following years.

Бојан Иванов, „§4. багатела (за Сашо Ордановски)“, Форум аналитика 12. [Ivanov, Bojan (2016) '§4. bargain (for Sašo Ordanoski)', Forum analitics 12.] [https://www.facebook.com/bojan. ivanov/posts/10208361649745130]

17 Jacques Rancière, "Modernity Revisited," in Modern Times ( Zagreb: Multimedijalni institut, 2017), 58 . 
Debord, Guy (1994) The Society of the Spectacle. [Trans. Donald NicholsonSmith] New York: Zooe Books.

Иванов, Бојан(2016а) „Коментар“. [Ivanov, Bojan (2016a) 'Comment'.] [https://www. facebook.com/notes/nebojša-vilić/status-100-6832-што-ми-се-случи-во-четвртокот-на-5маj-2016/10153801452193220/]

Иванов, Бојан(2016b) „§4. багатела (за Сашо Ордановски)“, Форум аналитика 12. [Ivanov, Bojan (2016b) ‘§4. bargain (for Sašo Ordanoski)’, Forum analitics 12.] [https://www.facebook. com/bojan.ivanov/posts/10208361649745130]

Лисман, Конрад Пол (2012) Теорија на необразованието. Заблудите на опитеството на знаење. Скопје: Темплум. [Liessmann, Konrad Paul (2006) Theorie der Unbildung. Die Irrtümer der Wissensgesellchaft. Wien: Paul Zsolnay Verlag.]

Rancière, Jacques (1991) The Ignorant Schoolmaster. [1987] [Transl. Kristin Ross] Stanford, California: Stanford University Press.

Rancière, Jacques (2007) The Future of the Image. [2003] [Transl. Gregory Elliott] London and New York: Verso.

Rancière, Jacques (2009) The Aesthetic Unconscious. [2001] [Transl. Debra Keates\& James Swenson] Cambridge, UK and Malden, MA: Polity Press.

Rancière, Jacques (2010) Dissensus. On Politics and Aesthetics. [Edited and Translated by Steven Corcoran] London and New York: Continuum.

Rancière, Jacques (2011) Mute Speech. Literature, Critical Theory, and Politics. [1998] [Transl. by James Swenson with an Introduction by Gabriel Rockhill] New York: Columbia University Press.

Rancière, Jacques (2017) ‘Modernity Revisited’, pp. 58-86 in Modern Times. Zagreb: Multimedijalni institut.

Schirato, Tony \& Jen Webb (2004) 'Selling the Visual', pp. 151-68 in Reading the Visual. Crows Nest: Allen \&Linwin. 


\section{DA LI ĆE UMRETI MARINA ABRAMOVIĆ?}

\section{Svetlana Racanović}

Postupno, a zatim žestoko ubrzanje i diversifikovanje životnih i umetničkih izbora i angažmana reflektuje želju umetnice Marine Abramović da se u njenu performans mašinu usadi i stavi u pogon sila perpetumobilnosti. Toliko puta u njenom životu i radu opipavana i izazivana linija kraja, okončanja, nemanja-posle-toga, dakle, smrti, time se ne bi melanholično potvrđivala ali ni očajnički poricala niti divlje zauzdalavala, već bi se ta linija poslednjeg horizonta snažno zarotirala i umesto fatalne postala vitalna, umesto granične postala ciklična, ona koja (se) vraća, ona iz koje se biva (hiper)produktivnim. Različitim strategijama i praksama ona pokušava da zakrivi strelu vremena, da zakoči, uspori, poremeti, sabotira njegovu logiku. Ona želi da rekonstruiše, revitalizuje, podmladi, produži trajanje tela svoje umetnosti, tela umetnosti performansa i, konsekventno, sopstvenog biološkog tela posežući za različitim metodama i mehanizmima supstituisanja, tehničke multiplikacije, ekstenziranja, virtualizacije, pa i spektakularizacije sopstvenog tela i tela svoje umetnosti.

KLJUČNE REČI: MARINA ABRAMOVIĆ, PERFORMANS, EFEMERNOST, SMRT, PODMLAĐIVANJE TELA UMETNOSTI/ UMETNIKA, TRAJNOST

\section{OD ESTETSKOG KA ETIČKOM:}

\section{MIT I METAFORA KAO MODUS NARATIVA KOD LEVINASA Kristina Bojanović}

U ovom radu pokušaću da pokažem da Levinasova etika sadrži estetiku mitološke naracije koja ima metaforično ("kao da" značenje) i arhetipsku dimenziju, dok ću odnos između etike i estetike nastojati da objasnim posredstvom Levinasovog poimanja erosa. Ovi ciljevi zasnovani su na pretpostavci da mit predstavlja uroboričku osnovu Levinasove filozofije kojom je on uspeo da se otrgne iz egologije zapadne misli, ali i iz iskustva vlastite imaginacije. Mit govori o univerzalijama posredstvom različitih predstava, odnosa, likova itd. Imajući u vidu da su univerzalije arhetipovi, i da svi arhetipovi u istoriji čovečanstva imaju estetsku dimenziju, Levinasova filozofija "nudi" arhetipske strukture mitova kroz operativne pojmove poput erosa, beskonačnosti, ženskog, traume, materinstva, plodnosti... Pokušaću da pokažem da je Levinasovo uspostavljanje etike kao prve filozofije zasnovano na jeziku metafora kao gradivnog i nesaznatljivog temelja psihe.

KLJUČNE REČI: MIT, METAFORA, EROS, ETIKA, ESTETIKA, DRUGO, ŽENSKO

\section{AISTHETON (ČULNO OPAŽANJE) U VREME DRUŠTVENO-POLITIČKE KRIZE Nebojša Vilić}

Glavna namera ovog rada je da predloži način razumevanja odnosa između estetike i politike u misli Žaka Rensijea kao teorijskog instrumenta za primenu u konkretnoj situaciji protesta. Nadalje, protest će se uzimati samo kao društveni događaj uživo, ali i kao telesno iskustvo sa posledicama i rezultatima koji proizlaze iz toga. Polazeći od Rancijerovog stanovišta raspodele čulnog i načina na koji predmet bez glasa mora da dostigne svoje pravo na govor, ovaj rad se bavi nekolicinom tema prema kojima se može zaključiti da samo fizičko prisustvo tokom protesta daje mogućnost subjektu da taj čin oseti razumno. Ovo je prilično različit pristup telesnog razumevanju sveta i iskustava poznatih kao odnos umetnosti i estetike, označavajući aistheton i kao istovremenog nosioca značenja političkog. Studija slučaja korišćena za ovu primenu je takozvana Obojena revolucija, i „bojenje“ makedonske kapije u Skoplju, u Makedoniji.

KLJUČNE REČI: AISTHETON, KOLEKTIV, TELESNOST, REŽIM DOŽIVLJAJA, NEMI GOVOR, POLITIKA, PROTEST, RAZUMAN 